\title{
A multirezisztens infekciók rizikófaktorainak vizsgálata két intenzív osztályon
}

\author{
Szabó Marcell dr. ${ }^{1,2}$ - Kanász Noémi oh. ${ }^{3}$ \\ Darvas Katalin dr. ${ }^{2}$ - Gál János dr. ${ }^{2}$ \\ Semmelweis Egyetem, Általános Orvostudományi Kar, \\ ${ }^{1}$ I. Sebészeti Klinika, ${ }^{2}$ Aneszteziológiai és Intenzív Terápiás Klinika, Budapest \\ ${ }^{3}$ Semmelweis Egyetem, Általános Orvostudományi Kar, Budapest
}

Bevezetés: Az intenzív osztály kedvező környezet a nosocomialis infekciók számára, nagy részüket multirezisztens baktériumok okozzák.

Célkitüzés: Intenzív osztályon szerzett multirezisztens infekciók rizikófaktorainak azonosítása.

Módszer: Obszervációs vizsgálatot végeztünk két egyetemi, egy multidiszciplináris és egy sebészeti intenzív osztályon 2014. szeptember 1-jétől 2015. november 30-ig. Azokat a betegeket vontuk be, akiknél az intenzív felvételt követő $\geq 48$ óra után meghatározott baktériumok (P. aeruginosa, E. coli, K. pneumoniae, A. baumanni, S. aureus, S. epidermidis, E. faecium, E. faecalis és multirezisztens változataik) valamelyike okozott elsőként infekciót. Multirezisztens (MRB) és nem multirezisztens (n-MRB) csoportot képeztünk. Rögzítettük a diabetes, COPD, dohányzás, alkoholizmus, akut mútétek és a daganatos betegségek prevalenciáját. Szerepüket a két osztály betegeinél együttesen értékeltük. Az állapotsúlyosságot a felvételi SAPS-II, illetve a pozitív tenyésztés napján számolt SOFA-pontszámokkal jellemeztük. Felmértük a megelőző intenzív terápia, lélegeztetés és antibiotikum-kezelés időtartamát.

Eredmények: A multidiszciplináris ITO-n 627, a sebészetin 1096 felvétel történt. A beválasztási kritériumok 79, illetve 57 esetben teljesültek. Előbbi osztályon az MRB-csoportba 41 (48,1\%), az n-MRB-csoportba 38 (51,9\%) beteg került. Utóbbi osztályon $31(54,4 \%)$ és $26(45,6 \%)$ beteg került a két csoportba. A dohányzás elősegítette a multirezisztens baktériumok jelenlétét (RR: 1,44; CI 95\%: 1,04-2,0; $\mathrm{p}=0,048$ ). Daganatos betegségek esetében az n-MRB-k kerültek többségbe (RR MRB-re: 0,68; CI 95\%: 0,47-0,97; p =0,026), a többi társbetegség szerepe nem volt szignifikáns. Az állapotsúlyossági pontszámok egyik osztályon sem különböztek a két csoportban. Nem tudtunk különbségeket kimutatni a megelőző intenzív kezelés, gépi lélegeztetés vagy antibiotikus kezelés hosszában sem.

Következtetés: A vizsgált osztályokon profiljától függetlenül MRB-rizikófaktornak bizonyult a dohányzás. Időhöz kötött rizikófaktort nem tudtunk azonosítani.

Orv Hetil. 2017; 158(32): 1259-1268.

Kulcsszavak: intenzív, multirezisztens, nosocomialis, infekció

\section{Identification of risk factors of multiresistant infections on two intensive care units}

Introduction: Intensive care units are favourable environment for infections, many of them are caused by antibiotic resistant bacteria.

Aim: Identifying risk factors of ICU-acquired multiresistant infections.

Method: We performed observational study on two academic intensive care units (a multidisciplinary and a surgical ICU) between $01 / 09 / 2014$ and 30/11/2015. Patients with a first infection caused by predefined organisms (P. aeruginosa, E. coli, K. pneumoniae, A. baumanni, S. aureus, S. epidermidis, E. faecium, E. faecalis or their multiresistant homologues) verified $\geq 48 \mathrm{~h}$ following admission were divided into two groups according to multiresistant $(\mathrm{MRB})$ and non-multiresistant (n-MRB) bacteria. Prevalence of diabetes, COPD, smoking, alcoholism, acute surgery, malignancy were recorded. Their role was evaluated on pooled populations. Illness severity was marked by SAPSII at admission and SOFA-score on day of positive culture. We also noted the length of stay, mechanical ventilation, antibiotic treatment. 
Results: Multidisciplinary ICU had 627, the surgical 1096 admissions. On the formal unit MRB group had 41 (48.1\%), the n-MRB had $38(51.9 \%)$ patients. On the latter unit $31(54.4 \%)$ and $26(45.6 \%)$ patients were involved. Smoking favoured multiresistant bacteria (RR 1.44 CI95\% $1.04-2.0 ; \mathrm{p}=0.048$ ). In case of malignancies $\mathrm{n}-\mathrm{MRB}$ were more prominent ( $R R$ of MRB 0.68 CI95\% 0.47-0.97; $\mathrm{p}=0.026$ ), other comorbidities had no significant impact. Illness severity scores did not differ at any of the ICUs. Preceding length of stay, days on mechanical ventilation or on antibiotics were similar in each group on both ICUs.

Conclusion: Smoking was revealed as a risk factor for MRB on our ICUs. We were not able to identify time-dependent risk factors.

Keywords: intensive care, multidrug resistance, nosocomial, infection

Szabó M, Kanász N, Darvas K, Gál J. [Identification of risk factors of multiresistant infections on two intensive care units]. Orv Hetil. 2017; 158(32): 1259-1268.

(Beérkezett: 2017. május 31.; elfogadva: 2017. június 22.)

\section{Rövidítések}

$\mathrm{BAL}=$ bronchoalveolaris lavage $; \mathrm{CFU}=$ (colony forming unit $)$ kolóniaformáló egység, „csíraszám”; COPD = (chronic obstructive pulmonary disease) krónikus obstruktív tüdőbetegség; CVK = centrális vénakanül; ESBL = extended spectrum of beta-lactamase; H2RA = hisztaminreceptor-2-antagonisták; $\mathrm{HK}=$ hemokultúra; $\mathrm{ITO}=$ intenzív terápiás osztály; MACI = multirezisztens Acinetobacter baumanni (a közkeletű rövidítés valójában kiterjedten rezisztens törzset jelöl); MDR = multidrogrezisztens; $\mathrm{MRB}=$ multirezisztens baktérium; MRSA = meticillinrezisztens Staphylococcus aureus; MRSE = meticillinrezisztens Staphylococcus epidermidis; $\mathrm{n}-\mathrm{MRB}=$ nem multirezisztens baktérium; PDR = pándrogrezisztens; SAPS-II = Simplified Acute Physiology Score II; SOFA = Sepsis-related Organ Failure Assessment; VRE = vancomycinrezisztens Enterococcus; $\mathrm{XDR}=($ extensively drug resistant $)$ kiterjedten rezisztens

Az intenzív osztályokon (ITO) világszerte és hazai viszonyok között is kiemelkedő az infekció miatt kezelt betegek aránya, a szeptikus sokk pedig a leggyakoribb sokkállapot $[1,2]$. Az infekciók azonban sok esetben az egészségügyi ellátás során érik a betegeket, a véráramfertőzések 76\%-a pedig az intenzív ellátás során lép fel [3]. Nem teszi biztatóvá a helyzetet, hogy az ITO nosocomialis infekciói minden vizsgált végpontban (mortalitás, kezelés időtartama, költségvonzata) rosszabb kimenetellel függenek össze [3-5].

Ezen fertőzések kórokozói között kifejezetten gyakoriak az antibiotikum-rezisztens törzsek: a legalább három antibiotikum-csoportban rezisztenciát mutató multidrogrezisztens (MDR) és a maximum két antibiotikumcsoportra érzékeny kiterjedten rezisztens (XDR) törzsek terjedése is aggasztó mértéket öltött [6]. Bár a korábbi problémabaktériumok, elsősorban a Gram-pozitívak (például a meticillinrezisztens Staphylococcus aureus), valamelyest visszaszorulóban vannak, de arányaikat és teljes prevalenciájukat tekintve is egyre nagyobb nehézséget jelentenek a Gram-negatívak (ESBL-termelő bélbaktériumok, multidrogrezisztens Pseudomonas aeruginosa,
Acinetobacter baumanni stb.) [7]. Az elmúlt évek fejleménye volt néhány, hazánkban még alulreprezentált baktérium országos szinten is megfigyelhetố elszaporodása, illetve vancomycinrezisztens Enterococcusok megjelenésével is számolhatunk, ezzel kapcsolatos saját tapasztalatainkról korábban beszámoltunk $[8,9]$.

Bár a virulencia fokozódása nem igazolható minden MRB esetében, a kiterjedt rezisztencia következményei nagy terhet helyeznek az ellátórendszerre, hiszen a nosocomialis fertőzés okozta szövődményeken túl, késleltetheti a hatékony empirikus antimikrobiális terápiát, ezáltal rontva a kimenetelt $[10,11]$. Ráadásul kényszerpályára terelheti a kezelést, mivel sok esetben csak néhány hatékony antibiotikumra szúkülő eszköztár több esetben már kevésbé hatékony, több mellékhatással és általánosságban magasabb költségvonzattal járó terápiához vezethet.

A fentiek felhívják a figyelmet a megelőzés jelentőségére. A megfelelő minőségú infekciókontroll, különös tekintettel a megfelelő kézhigiénére, általánosságban csökkentheti a nosocomialis infekciók előfordulását [12], az azonban már kérdéses, hogy azonosíthatóak-e a multirezisztens infekciók rizikófaktorai. Vizsgálatunkban a problémás kórokozókat specifikusan elónyhöz juttató társbetegségeket és esetleges intenzív osztályos kezelési sajátságokat kívántuk azonosítani.

\section{Betegek és módszer}

A vizsgálat során prospektíven gyújtött adatokat retrospektív eset-kontroll elrendezés szerint elemeztük. A felhasznált adatok a betegellátás szokásos menetét követve auditadatok összegyújtésével kerültek a vizsgálat dokumentációjába.

\section{Betegek}

A Semmelweis Egyetem (SE) két intenzív osztályán folytattuk vizsgálatunkat. Az Aneszteziológiai és Intenzív Terápiás Klinika Kútvölgyi Intenzív Osztályán (a továb- 
biakban multidiszciplináris ITO), valamint az I. Sz. Sebészeti Klinika Intenzív Osztályán (a továbbiakban sebészeti ITO) gyújtöttünk adatokat 2014. szeptember l. és 2015. november 30. között. Azokat a betegeket választottuk be, akiknél az ITO-ra történt felvételüket követően legalább 48 órával elvégzett mikrobiológiai mintavétel az elöre meghatározott kórokozók valamelyikét (Staphylococcus aureus, koaguláznegatív Staphylococcusok, Enterococcus faecalis, illetve faecium, Escherichia coli, Klebsiella pneumoniae, Pseudomonas aeruginosa, Acinetobacter baumanni) és így az ITO-n szerzett fertőzést vagy kolonizációt igazolt. Minden beteg egyszer, az első pozitív minta alapján került bevonásra. A betegcsoportokat az igazolt kórokozó alapján határoztuk meg, a nem multirezisztens csoportban (n-MRB) azon betegek adatait értékeltük, ahol az azonosított kórokozó nem minősült MDR- vagy XDR-izolátumnak [6], a multirezisztens csoportba (MRB) az ezen kritériumoknak megfelelő kórokozókat hordozó betegek kerültek.

Kizárásra adott okot, ha az azonosított kórokozó az ITO-felvételt megelőzően vett mintában is jelen volt már, valamint, ha a beteg a megelőző 30 nap folyamán már részesült intenzív ellátásban más intézményben. A megelőző antibiotikum-terápia nem indokolta a kizárást.

A két részt vevő osztály adatait együttesen értékeltük a betegek demográfiai jellemzői és társbetegségei szerepének vizsgálatakor. Az ellátás jellemzőinek hatását a két osztály eltérő múködési sajátosságait, ellátási standardjait figyelembe véve, elkülönítve vizsgáltuk. Ennek megfelelően a multidiszciplináris ITO-n és a sebészeti ITO-n külön-külön végeztük az n-MRB- és az MRB-csoportok képzését és összehasonlítását.

\section{Mikrobiológiai vizsgálatok és a fertözések azonositása}

A vizsgálat ideje alatt a mintavétel az osztályokon megszokott rend szerint történt. Infekcióra utaló klinikai kép esetén minden esetben történt szúrt és a több mint 48 órája in situ lévő kanülökből vett hemokultúravétel. További célzott leoltások a valószínúsíthető infekciók alapján a kezelőorvos rendelése szerint történtek. Alsó légúti fertőzés gyanúja esetén mély légúti mintavétel (tracheaaspirátum és/vagy bronchoalveolaris mosófolyadék), felmerülő uroinfekció esetén katéteres vizeletminta, a mütéti területet érintő fertőzés valószínűsítése esetén a gócból sebészi vagy percutan mintavétel történt. Rendszeres surveillance-célú mintavételek nem történtek, kivéve, ha a kórházhigiénés szolgálat speciális céllal (valamely multirezisztens kórokozó halmozott előfordulása esetén) ezt eseti jelleggel nem javasolta külön. Szûrő jelleggel a vizsgált időszakban leoltások (garat, hónalj, perianalis tájék, illetve vizelet) csak az ápolási és krónikus ellátást nyújtó egységekből érkezett betegeknél, az előzetesen tudottan MRB-érintett betegekkel kontaktusba kerülteknél, valamint a kezelőorvos egyéni döntése alapján történt. Lokális gyulladásos jelek esetén, illetve egyéb nyilvánvaló ok nélkül infekciós jeleket mutató betegeinknél, ezek hiányában is, az intravascularis kanülöket cseréltük, a kanülvéget mikrobiológiai vizsgálatra küldtük. A sebészeti ITO-n lélegeztetett beteg felvételekor, 24 órán túli lélegeztetést követően történő extubációkor infekciós jelek nélkül is tracheaaspirátum-tenyésztés történt.

A minták feldolgozását az SE Mikrobiológiai Intézete végezte, az antibakteriális szerekre adott érzékenységet korongdiffúziós módszerrel a European Committee on Antimicrobial Susceptibility Testing (EUCAST) vonatkozó ajánlásai alapján [13] határozták meg.

A mikrobiológiai pozitivitást abban az esetben tekintettük infekció részjelenségének, ha a klinikai kép megfelelt a HELICS (Hospitals in Europe Link for Infection Control through Surveillance) definíciói alapján [14] meghatározott klinikai és mikrobiológiai kritériumainknak, amelyeket az 1. táblázatban mutatunk be. Az így diagnosztizálható infekciók közül a pneumoniát, a kanülasszociált fertőzéseket, valamint a műtéti területi fertőzéseket és a húgyúti fertőzéseket vettük figyelembe.

\section{Állapotsúlyosság}

$\mathrm{Az}$ egyes betegek intenzív osztályos felvételének napján rögzítettük a Simplified Acute Physiology Score II (SAPS II) pontszám értékét [15]. A beválasztás alapjául szolgáló mikrobiológiai minta levételének napján meghatároztuk a Sepsis-related Orgran Failure Assessment (SOFA-) pontszámot [16].

\section{Társbetegségek}

Az osztályokra jellemző beteganyag társbetegségei közül a multirezisztencia potenciális rizikófaktoraként a krónikus obstruktív tüdőbetegséget (COPD), a diabetes mellitust, az alkoholizmust, a dohányzást, a malignus alapbetegség meglétét, valamint a jelen ellátás során pozitív mintavételt megelőzően lezajlott akut mütéti beavatkozást mértük fel.

Az egyes társbetegségek meglétét a betegdokumentációban rögzített adatok alapján vettük figyelembe. COPD fennállását véleményeztük: 1 . ha korábban pulmonológus diagnosztizálta vagy 2 . ha a preoperatív kivizsgálás során légzésfunkciós vizsgálat készült, amelyen a $\mathrm{FEV}_{\mathrm{l}} / \mathrm{FVC}<70 \%$-os értéke igazolódott, vagy 3 . az ITO-ra való felvétel oka légzési elégtelenség volt, amelyet a kezelőorvosok COPD akut exacerbatiójának minősítettek. Diabetes mellitus jelenlétét állapítottuk meg, függetlenül attól, hogy 1 -es vagy 2 -es típusa állt fenn, a következő esetekben: a betegség ismert, a beteg erre korábban már kezelést kapott, korábban diagnosztizálatlan volt, de az intenzív felvétel diabeteses sürgősségi állapothoz kötődött. Dohányzást vettünk figyelembe aktív dohányzás esetén, függetlenül a naponta elfogyasztott dohánytermékek mennyiségétől, illetve aktuálisan a felvételük előtt nem dohányzó betegeknél is, ha a do- 
Az infekciók és a kolonizációk elkülönítésére használt klinikai és mikrobiológiai kritériumrendszer. A HELICS [14] ajánlása alapján az intézményeinkben elérhető eszközökre adaptált változat

\begin{tabular}{|c|c|}
\hline Pneumonia & $\begin{array}{l}\text { Két vagy több mellkasröntgen és/vagy CT } \\
\text { pulmonalis vagy kardiális alapbetegség esetén, } \\
\text { amelyen infiltrátum van } \\
\text { Egy mellkasröntgen vagy CT pulmonalis vagy } \\
\text { kardiális alapbetegség nélkül, amelyen infiltrátum } \\
\text { van } \\
\text { És legalább egy az alábbiak közül: } \\
\text { Más okkal nem magyarázható láz >38 }{ }^{\circ} \mathrm{C} \\
\text { WBC <4 vagy >12 G/L } \\
\text { És legalább egy az alábbiak közül: } \\
\text { Újonnan megjelenó purulens vagy megváltozó } \\
\text { jellegú/mennyiségú köpet vagy légúti váladék } \\
\text { Köhögés/dyspnoe/tachypnoe } \\
\text { Típusos hallgatózási lelet } \\
\text { Romló gázcsere } \\
\text { És legalább egy az alábbiak közül: } \\
\geq 10^{5} \text { CFU tracheából } \\
\geq 10^{4} \text { CFU BAL-ból } \\
\text { Pozitív tenyésztés pleuralis folyadékból } \\
\text { Pozitív hemokultúra más forrás hiányában }\end{array}$ \\
\hline Kanülinfekció & $\begin{array}{l}\text { A kanülből }>10^{3} \text { CFU tenyészik, a kanüleltávolítás } \\
\text { után }<48 \text { h-n belül szű́nő láz vagy hidegrázásos } \\
\text { epizódok } \\
\text { A kanülből }>10^{3} \text { CFU tenyészik, a } \\
\text { kanüleltávolítástól } \pm 48 \text { h-n belül pedig pozitív } \\
\text { hemokultúra ugyanazon kórokozóval ( } S \text {. } \\
\text { epidermidisból } 2 \mathrm{HK}) \\
\text { Szúrt és CVK-ból vett hemokultúra ugyanazon } \\
\text { kórokozóval, a CVK-ból vett minimum } 2 \text { h-val } \\
\text { hamarabb pozitív }\end{array}$ \\
\hline Uroinfekció & $\begin{array}{l}\geq 10^{5} \text { CFU vizeletból } \\
\text { És legalább egy az alábbiak közül: } \\
\text { Láz }>38^{\circ} \mathrm{C} \\
\text { Suprapubicus fájdalom vagy érzékenység } \\
\text { Dysuria } \\
\text { Uroszepszis (pozitív HK ugyanazon kórokozóval) } \\
\text { és láz }>38^{\circ} \mathrm{C} / \text { hidegrázás/hipotenzió }\end{array}$ \\
\hline $\begin{array}{l}\text { A műtéti terület } \\
\text { fertőzése }\end{array}$ & $\begin{array}{l}\text { Mútét <30 napon belül } \\
\text { Pozitív tenyésztés lokális mintából vagy pozitív } \\
\text { HK más ok nélkül ( } \text { S. epidermidis esetén } 2 \text { ) } \\
\text { És legalább egy az alábbiak közül: } \\
\text { Bármely lokális gyulladásos jel (fájdalom, } \\
\text { duzzanat, melegség stb.) } \\
\text { Láz >38 }{ }^{\circ} \mathrm{C} \\
\text { Szeptikus sebszétválás/reoperáció szükségessége } \\
\text { Tályog fizikálisan vagy képalkotóval igazolva } \\
\text { Sebész vagy osztályos orvos diagnosztizálja }\end{array}$ \\
\hline
\end{tabular}

hányzásról való leszokás óta nem telt még el két hónap. Alkoholizmust dokumentáltunk a következók valamelyikének fennállása esetén: ha ezt pszichiáter diagnosztizálta, ha a bevallott rendszeres fogyasztás (valószínúsíthetôen) meghaladta a heti 14 italnak megfelelő mennyiséget [17], illetve, ha a fogyasztott mennyiség nem volt ismert, de a betegnél vagy megvonásos tünetet észleltünk, vagy a kezelőorvos az ITO-n szubsztitúciós terápiát rendelt. Akut mútétet vettünk figyelembe, ha a felvétel oka akut mútét vagy közvetlenül azzal összefüggésbe hozható szövődmény volt, vagy akut mútét történt az ITO-n fekvés alatt a bevonás alapjául szolgáló tenyésztés levételéig. Malignus alapbetegséget regisztráltunk, ha a kórházi felvételkor ismert rosszindulatú daganatos betegség állt fenn, vagy a kezelés alatt igazolódott, vagy a megelőző fél évben onkológiai kezelés zajlott.

\section{Terápiás jellemzők}

A terápia jellemzői közül rögzítettük a kórházban, az intenzív osztályon, illetve a lélegeztetve telt és az antibiotikum-terápiás napok számát a pozitív mikrobiológiai minta levételéig. Felmértük a táplálás módját.

Parenteralis táplálásként vettünk figyelembe minden esetet, ha a beteg megelőzően ilyen kezelésben részesült az intenzív osztályon, függetlenül annak időtartamától. Rögzítettük a stresszulcus profilaxisának alkalmazását és módszerét (protonpumpagátló [PPI] vagy hisztaminreceptor-2- [H2R-] antagonista).

\section{Statisztikai elemzés}

A statisztikai elemzéshez StatsDirect 3 alkalmazást használtunk (StatsDirect statistical software. http://www. statsdirect.com. StatsDirect Ltd., Egyesült Királyság). Normáleloszlású adatainkat átlagértékkel és szórással, a nem normális eloszlásúakat a medián értékkel és 2575\%-os interkvartilistartománnyal (IQR) jellemeztük. Normáleloszlású független folytonos változók összehasonlításához Student-féle kétmintás t-próbát alkalmaztunk. Nem normális eloszlások esetében Mann-Whitney U-tesztet végeztünk. A társbetegségek rizikót befolyásoló hatását relatívrizikó- (RR-) számítással értékeltük, itt a statisztikai valószínúséget $\chi^{2}$-próbával határoztuk meg, amennyiben a kontingenciatáblák valamely értéke 5 vagy annál kisebb volt, úgy Fisher-féle egzakt próbát vettünk igénybe. Minden próba esetében kétszélú eloszlást feltételeztünk. A statisztikai szignifikancia határát $p<0,05$-nál határoztuk meg.

\section{Eredmények}

A vizsgálat alatt a multidiszciplináris ITO-n 627 , a sebészetin 1096 felvétel történt. A beválasztási kritériumok 79 , illetve 57 esetben teljesültek. Előbbi osztályon az MRB-csoportba 41 (48,1\%), az n-MRB-csoportba 38 $(51,9 \%)$ beteg került. Utóbbi osztályon $31(54,4 \%)$ és 26 
2. táblázat |Az egyes osztályokon azonosított kórokozók gyakorisága százalékban, illetve esetszámuk zárójelben feltüntetve

\begin{tabular}{|c|c|c|c|c|c|c|c|c|}
\hline \multirow{3}{*}{$\begin{array}{l}\text { Species } \\
\text { S. aureus }\end{array}$} & \multicolumn{4}{|c|}{ Multidiszciplináris ITO $(\mathrm{n}=79)$} & \multicolumn{4}{|c|}{ Sebészeti ITO $(\mathrm{n}=57)$} \\
\hline & \multicolumn{2}{|c|}{ MRB } & \multicolumn{2}{|c|}{$\mathrm{n}-\mathrm{MRB}$} & \multicolumn{2}{|c|}{$\mathrm{MRB}$} & \multicolumn{2}{|c|}{$n-M R B$} \\
\hline & $5,1 \%$ & (4) & $5,1 \%$ & $(4)$ & $5,3 \%$ & (3) & $3,5 \%$ & (2) \\
\hline Koaguláznegatív Staphylococcusok & $7,6 \%$ & (6) & $3,8 \%$ & (3) & $7,2 \%$ & (4) & $7,2 \%$ & (4) \\
\hline E. faecalis & $1,3 \%$ & (1) & $3,8 \%$ & (3) & $0,0 \%$ & $(0)$ & $7,2 \%$ & (4) \\
\hline E. faecium & $5,1 \%$ & (4) & $6,3 \%$ & (5) & $0,0 \%$ & $(0)$ & $1,8 \%$ & (1) \\
\hline E. coli & $0,0 \%$ & $(0)$ & $2,5 \%$ & (2) & $1,8 \%$ & (1) & $3,5 \%$ & (2) \\
\hline K. pneumoniae & $2,5 \%$ & (2) & $2,5 \%$ & $(2)$ & $3,5 \%$ & (2) & $5,3 \%$ & (3) \\
\hline P. aeruginosa & $20,3 \%$ & $(16)$ & $27,9 \%$ & $(22)$ & $8,8 \%$ & (5) & $17,5 \%$ & $(10)$ \\
\hline A. baumanni & $6,3 \%$ & $(5)$ & $0,0 \%$ & $(0)$ & $28,1 \%$ & (16) & $0,0 \%$ & $(0)$ \\
\hline
\end{tabular}

3. táblázat |A részt vevő osztályokon tapasztalt infekciós arányok, illetve az észlelt fertőzések megoszlása. Zárójelben az esetszámokat tüntetjük fel

\begin{tabular}{|c|c|c|c|c|c|c|c|c|}
\hline \multirow{3}{*}{$\begin{array}{l}\text { Infekció típusa } \\
\text { Pneumonia }\end{array}$} & \multicolumn{4}{|c|}{ Multidiszciplináris ITO } & \multicolumn{4}{|c|}{ Sebészeti ITO } \\
\hline & \multicolumn{2}{|c|}{ MRB } & \multicolumn{2}{|c|}{$\mathrm{n}-\mathrm{MRB}$} & \multicolumn{2}{|c|}{ MRB } & \multicolumn{2}{|c|}{$\mathrm{n}-\mathrm{MRB}$} \\
\hline & $44,7 \%$ & $(17)$ & $36,6 \%$ & (15) & $41,9 \%$ & (13) & $46,2 \%$ & (12) \\
\hline Mútéti terület fertőzései & $7,9 \%$ & $(3)$ & $17,1 \%$ & (7) & $25,8 \%$ & $(8)$ & $23,1 \%$ & (6) \\
\hline Kanülinfekció & $2,6 \%$ & (1) & $0,0 \%$ & (0) & $3,2 \%$ & (1) & $0,0 \%$ & $(0)$ \\
\hline Egyéb & $5,3 \%$ & $(2)$ & $2,4 \%$ & (1) & $0,0 \%$ & $(0)$ & $3,9 \%$ & (1) \\
\hline Összes infekció & $61,5 \%$ & (23) & $43,9 \%$ & (18) & $71,0 \%$ & (22) & $72,1 \%$ & (19) \\
\hline Kolonizáció & $39,5 \%$ & (15) & $56,1 \%$ & (23) & $29,0 \%$ & (9) & $26,9 \%$ & (7) \\
\hline
\end{tabular}

$(45,6 \%)$ beteg került a két csoportba. Az összesített értékelésekhez (demográfiai adatok és társbetegségek) így 69 MRB- és 67 n-MRB-beteg adatai álltak rendelkezésre.

\section{Demográfiai adatok}

A betegek átlagéletkora az MRB-csoportban 69,3 \pm 10,9 év, míg az n-MRB-csoportban ez 68,2 \pm 13,8 év volt $(p=0,299)$. A nemek arányát a két csoportban hasonlónak találtuk: az MRB-csoport 59,4\%-át, az n-MRB $62,7 \%$-át adták a férfiak $(p=0,696)$.

\section{Kórokozók}

A vizsgálatban részt vevő két intenzív osztályon azonosított baktériumok gyakoriságát a 2. táblázatban mutatjuk be. A két intenzív osztály a vizsgált időszakban sajátos jellemző kórokozóflórával rendelkezett. A leggyakoribb izolált baktérium a multidiszciplináris ITO-n nem multirezisztens $P$. aeruginosa volt, a sebészeti ITO-n legtöbbször kiterjedten rezisztens (XDR) A. baumannit izoláltak.

\section{Infekciók}

A két osztályon az infekciók aránya az MRB- és n-MRBbetegek körében nem különbözött szignifikánsan, azaz a multirezisztens baktériumok virulenciája nem haladta meg érdemben a nem multirezisztensekre jellemzőt. A multidiszciplináris ITO-n az MRB-k és az n-MRB-k is összesen 23-23 infekciót okoztak, amely 60,5\%-os és $57,5 \%$-os infekciós rátának felelt meg $(p=0,786)$. A sebészeti ITO-n 21, illetve 16 klinikailag is igazolható fertőzést találtunk, amely 67,7\%-os és 76,0\%-os fertőzési arányt jelent. Az egyes osztályokon azonosított infekciók típusát a 3. táblázatban mutatjuk be. Mindkét osztályon a pneumonia bizonyult a leggyakrabban előforduló infekciónak, amelyet a mútéti terület fertőzései, majd a kanülinfekciók követtek. A megnevezett kategóriák diagnosztikus kritériumait nem teljesítő, klinikai tünettel járó bacteriaemiák esetszámait az „egyéb” megjelölést viselő cellákban tüntettük fel. Itt is felhívjuk a figyelmet, hogy metodikánk nem az összes ITO-n szerzett infekció megoszlását reprezentálja, hanem a beválasztás alapjául szolgáló első ITO-n szerzett kórokozók klinikai relevanciáját.

\section{Állapotsúlyosság}

Az intenzív ellátás első napján felmért SAPS-II-pontszámok medián értéke a multirezisztens kórokozót akvirált csoportban 41 pont (IQR: 30-53), míg a nem multirezisztens kórokozóval fertőződő betegek esetében 39 pont (IQR: $21-53)$ volt $(p=0,403)$.

A bevonás alapjául szolgáló pozitív tenyésztés napján felmért medián SOFA-pontszám az MRB-csoport betegei között 4 volt (IQR: 3-6), az n-MRB-betegek között 
4. táblázat | Populációs jellemzők és társbetegségek a két osztályon, illetve a meghatározott betegcsoportokban. Gyakorisági adatok százalékban, esetszámok zárójelben feltüntetve

\begin{tabular}{|c|c|c|c|c|c|c|c|c|c|c|}
\hline \multirow[t]{2}{*}{ Jellemző } & \multicolumn{5}{|c|}{$\begin{array}{l}\text { Multidiszciplináris ITO } \\
\qquad(\mathrm{n}=79)\end{array}$} & \multicolumn{5}{|c|}{$\begin{array}{l}\text { Sebészeti ITO } \\
\qquad(\mathrm{n}=57)\end{array}$} \\
\hline & \multicolumn{2}{|c|}{$\begin{array}{c}\text { MRB } \\
(\mathrm{n}=41)\end{array}$} & \multicolumn{2}{|c|}{$\begin{array}{l}n-M R B \\
(n=38)\end{array}$} & $\mathrm{p}$ & \multicolumn{2}{|c|}{$\begin{array}{c}\text { MRB } \\
(\mathrm{n}=31)\end{array}$} & \multicolumn{2}{|c|}{$\begin{array}{l}n-M R B \\
(n=26)\end{array}$} & $\mathrm{p}$ \\
\hline Életkor & \multicolumn{2}{|c|}{$69,3 \pm 10,8$ év } & \multicolumn{2}{|c|}{$70,4 \pm 13,1$ év } & 0,556 & \multicolumn{2}{|c|}{$69,4 \pm 11,1$ év } & \multicolumn{2}{|c|}{$64,87 \pm 14,6$ év } & 0,337 \\
\hline Férfiak & $63,2 \%$ & $(24)$ & $56,1 \%$ & $(23)$ & 0,525 & $54,8 \%$ & $(17)$ & $73,1 \%$ & (19) & 0,155 \\
\hline COPD & $23,7 \%$ & $(9)$ & $24,4 \%$ & $(10)$ & 0,951 & $25,8 \%$ & (8) & $15,4 \%$ & (4) & 0,348 \\
\hline Diabetes & $42,1 \%$ & $(16)$ & $31,7 \%$ & $(13)$ & 0,365 & $22,6 \%$ & (7) & $19,2 \%$ & $(5)$ & 0,942 \\
\hline Dohányzás & $31,6 \%$ & (12) & $14,6 \%$ & (6) & 0,030 & $25,8 \%$ & (8) & $15,5 \%$ & (4) & 0,348 \\
\hline Alkoholizmus & $18,4 \%$ & (7) & $12,2 \%$ & (5) & 0,746 & $22,6 \%$ & (7) & $23,1 \%$ & (6) & 0,982 \\
\hline Akut mütét & $21,1 \%$ & (8) & $34,2 \%$ & $(14)$ & 0,248 & $45,2 \%$ & (14) & $69,2 \%$ & (18) & 0,067 \\
\hline Malignitás & $26,3 \%$ & $(10)$ & $51,2 \%$ & $(21)$ & 0,019 & $45,2 \%$ & $(14)$ & $57,7 \%$ & (15) & 0,410 \\
\hline SAPS-II felvételkor & \multicolumn{2}{|c|}{$\begin{array}{c}48 \\
(\text { IQR 39,3-58) }\end{array}$} & \multicolumn{2}{|c|}{$\begin{array}{c}44 \\
(\text { IQR 28-54) }\end{array}$} & 0,228 & \multicolumn{2}{|c|}{$\begin{array}{c}30 \\
(\text { IQR } 24-45,5)\end{array}$} & \multicolumn{2}{|c|}{$\begin{array}{c}36 \\
(\text { IQR 22,5-41,75) }\end{array}$} & 0,747 \\
\hline $\begin{array}{l}\text { SOFA a pozitív } \\
\text { tenyésztés napján }\end{array}$ & \multicolumn{2}{|c|}{5 (IQR 3-6) } & \multicolumn{2}{|c|}{$5(\mathrm{IQR} 3-6,25)$} & 0,860 & \multicolumn{2}{|c|}{$5($ IQR $2,25-7,5)$} & \multicolumn{2}{|c|}{3 (IQR 3-5) } & 0,487 \\
\hline
\end{tabular}

ez 5-nek (IQR 3-6) bizonyult, amely nem mutatott szignifikáns különbséget $(p=0,405)$.

A két kitüntetett nap adatai alapján az állapotsúlyosság nem bizonyult rizikótényezőnek egyik baktériumcsoportra vonatkoztatva sem.

\section{Az egyes társbetegségek szerepe}

Az egyes társbetegségek gyakoriságát a részt vevő osztályokon, a két betegcsoport szerint a 4. táblázatban mutatjuk be. Az e szempontból együttesen vizsgált két osztályon az egyes kórokozócsoportokkal való fertőződés kockázatát relatívrizikó-számításával szemléltettük, amelyet az 1. ábrán mutatunk be. A COPD, a diabetes vagy az alkoholfüggőség nem befolyásolta érdemben az ITO-n szerzett multirezisztens kórokozók rizikóját. A dohányzás azonban jelentős mértékben elősegítette a multirezisztens baktériumok okozta kolonizációt, illetve infekciót. A relatív rizikó 1,44-nak bizonyult (CI 95\%: $1,04-2,0 ; p=0,048)$. A fentiek alapján a dohányzás ilyen hatása nem volt egyértelmúen összefüggésbe hozható az általa krónikusan okozott tüdőkárosodással (COPD). Ellentétes hatást észleltünk malignus betegségek jelenlétében. Ebben az esetben az MRB-rizikó 0,68-nak adódott (CI 95\%: 0,47-0,97; $p=0,026$ ). Ezt valójában fokozott n-MRB-rizikóként értékelhetjük. Hasonló tendenciát láttunk azon betegek esetében is, akik akut mútéti beavatkozáson estek át, azonban az összefüggés nem bizonyult szignifikánsnak, itt a relatív MRB-rizikó 0,71nak bizonyult (CI 95\%: 0,49-1,03; $p=0,059$ ).

\section{A terápiás jellemzők hatása}

Az intenzív terápia jellemző időtartamai a két osztály esetében külön-külön a 2. ábrán láthatóak. A pozitív mikrobiológiai mintavételig intenzív osztályon töltött idő, a gépi lélegeztetés időtartama, illetve az antibiotikum-terápia hossza is hasonlónak adódott az MRB- és az n-MRB-csoportokban mindkét osztályon.

Az intenzív felvételt megelőző kórházi ápolási napok számát ábrán nem tüntettük fel. A multidiszciplináris ITO-n medián 0 (IQR 0-1) nap volt jellemző az nMRB-csoportban, I (IQR 0-4) az MRB-csoportban, azaz magas volt a közvetlen területról vagy 24 órán belül ITO-ra vett betegek aránya $(p=0,158)$. A sebészeti ITO-n ugyanez az idő 2 (IQR 0-7), illetve 2,5 (IQR $0-9)$ napnak adódott $(p=0,469)$.

A pozitív tenyésztést megelőzően az intenzív osztályon töltött napok medián értéke a multidiszciplináris intenzív osztályon az MRB- és az n-MRB-csoportban egyaránt 7 napnak adódott, az interkvartilis tartomány 5-10 nap, illetve 5-11 nap volt $(p=0,775)$. A sebészeti ITO-n mindkét csoport betegei valamivel rövidebb, de egymástól érdemben nem eltérő időt töltöttek a vizsgált fertőzést megelőzően. Itt az MRB-csoportra medián 5 (IQR 3-8), az n-MRB-csoportra 4 (IQR 3-7) nap volt jellemző $(p=0,236)$.

A gépi lélegeztetett napok medián értéke a multidiszciplináris ITO-n 7 nap volt (IQR 2-8) az MRB-csoportban, 4 nap (IQR 3-9) pedig az n-MRB-csoportban $(p=0,122)$. Ugyanezen változók a sebészeti ITO-n megegyező csoportsorrendben 3 (IQR 1-6), valamint 2 (IQR 1-3) napnak adódtak $(p=0,260)$.

Kissé váratlanabb, hogy a megelőző antibiotikum-terápia hosszában sem találtunk különbséget az MRB- és n-MRB-betegek között egyik ITO-n sem. A multidiszciplináris ITO-n medián 9 napig (IQR 7-13) kaptak a későbbi MRB-betegek antibiotikumot, az n-MRB-csoportban pedig 8 napig (IQR $5-14)(p=0,455)$. A sebészeti ITO-n az MRB-betegek antibiotikum-terápiája 
$\leftarrow$ Inkább n-MRB

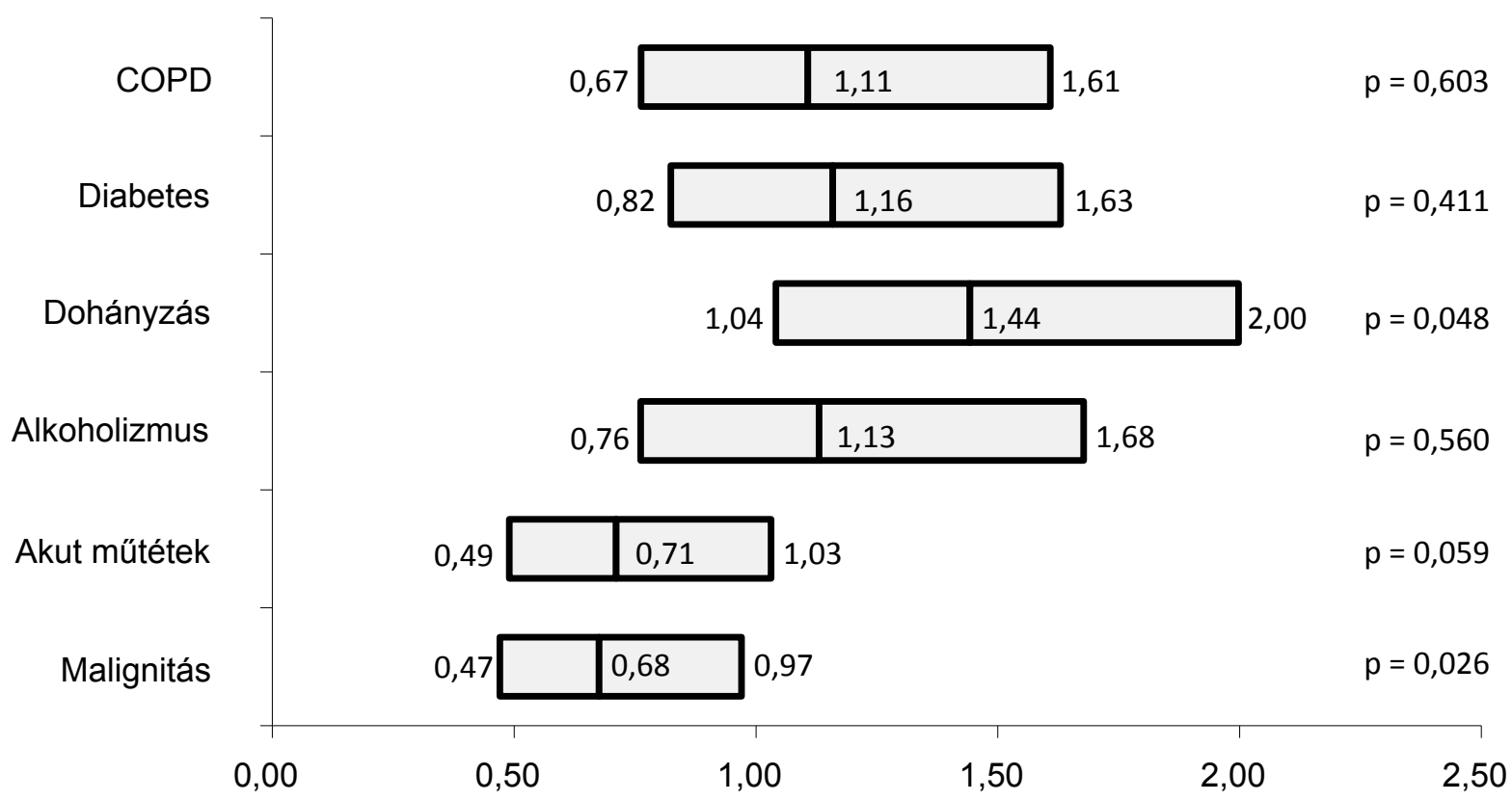

1. ábra Az egyes társbetegségek esetén észlelhető relatív rizikó multirezisztens baktériumok jelenlétére

ITO-n töltött napok

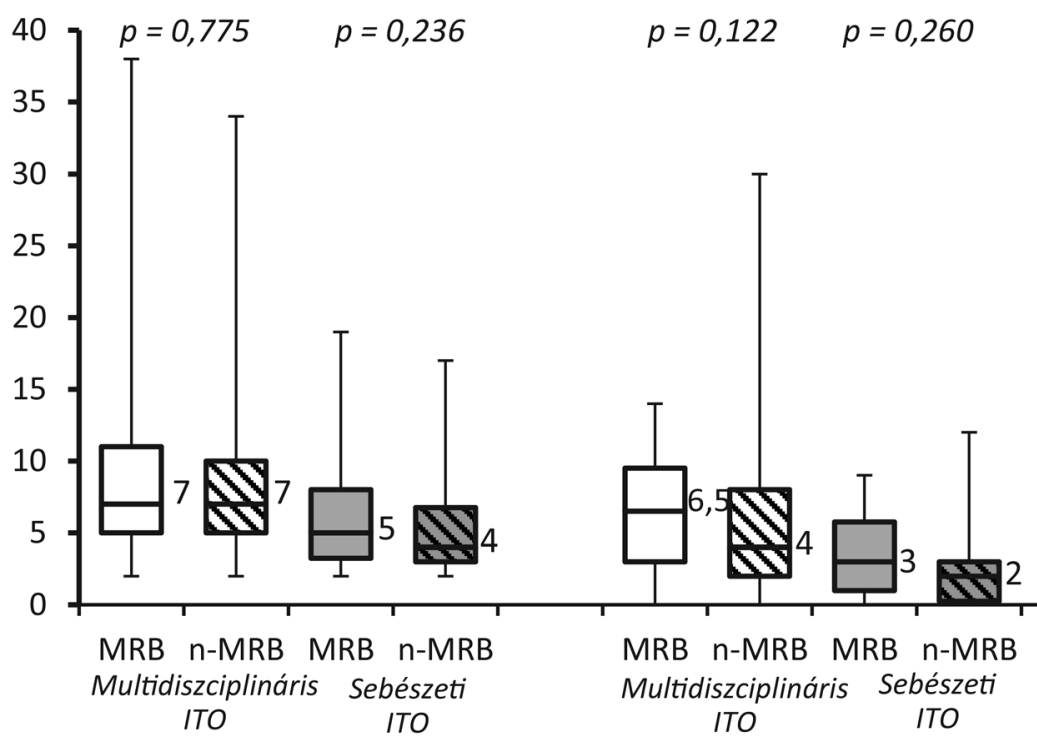

Antibiotikum-terápiás napok

$$
p=0,455 \quad p=0,439
$$

2. ábra

| Az intenzív osztályokon alkalmazott kezelések időtartama, medián értékek interkvartilistartománnyal és szélső értékekkel (hibasávok)

medián 8 nap volt (IQR 5-14), az n-MRB-betegeké 5 (IQR 3-10) $(p=0,439)$.

Ezen megfigyeléseink összességében nem igazoltak kezelési időtől egyértelmúen függő multirezisztencia melletti rizikófaktort a vizsgált osztályokon.

A parenteralis táplálás prevalenciáját vizsgálva mindkét osztályra igaz volt, hogy a két betegcsoportban ez a jellemző hasonlóan alakult: a multidiszciplináris ITO-n az
MRB-csoportban 26,3\% volt (10 fó), az n-MRB-csoportban pedig $26,8 \%$ (11 fó) kapott ilyen kezelést ( $p=$ $0,959)$, a sebészeti ITO-n ugyanezek a gyakoriságok $38,7 \%$ (10 fó) és 38,5\% (11 fó) voltak ( $p=0,985$ ).

A stresszulcus-profilaxis alkalmazása egyik osztályon sem tért el a két csoport betegei között. A multidiszciplináris osztály MRB-betegei 15,8\%-ban (6 fó) kaptak H2-receptor-antagonistát, 73,7\%-ban (28 fó) proton- 
pumpagátlót, n-MRB-betegei pedig 31,7\% (13 fó), illetve $51,2 \%$-ban (2l fö). Bár sejthető lenne egy esetleges tendencia, amely a PPI-k MRB-t favorizáló hatását felvetnék, azonban ez az eltérés sem bizonyult szignifikánsnak ( $p=0,120)$. Különösen megkérdőjeleznék egy ilyen összefüggés meglétét a sebészeti ITO-n tapasztaltak. A két csoport közötti különbség itt sem volt szignifikáns ( $p=0,693)$, éppen az MRB-csoportban volt valamelyest alacsonyabb a PPI-használat $(58,1 \%, 18$ fó) és kissé jobban reprezentált a H2RA-k alkalmazása (19,3\%, 6 fó). Az n-MRB-csoportban 69,2\% kapott PPI-t (18 fó), $15,4 \%$ ( 4 fó) H2RA-t.

\section{Megbeszélés}

Vizsgálatunkat két ITO bevonásával végeztük, de véleményünk szerint így is tehetünk néhány általánosítható megállapítást. Először is szembetünő, hogy bár hasonló betegforgalmú és méretű osztályokról volt szó, a jellemző nosocomialis baktériumflóra jelentős különbségeket mutatott. Ezt magyarázhatja ugyan az eltérő profil és az egyes osztályok napi múködését meghatározó, sok tekintetben eltérő munkarend, de valószínúbb, hogy a saját flóra kialakulása térben és időben változó, az egyes osztályokra jellemző folyamat, bár nagyobb régiókra jellemző trendekkel is kell számolnunk. Egy 2009-es nemzetközi felmérés, amely az ITO-n szerzett infekciók prevalenciáját és kimenetelét vizsgálta, jelentős regionális különbségeket talált a részt vevő osztályok között, ezek számunkra egyik kiemelendő példája a $P$. aeruginosa és az $A$. baumanni jelentősebb részaránya $(28,9 \%$ és $17,1 \%)$ Kelet-Európában a nyugat-európai országokhoz képest (17,1\% és 5,6\%) [18]. A két kórokozó a leggyakoribb baktériumnak bizonyult a mi felmérésünkben is, a multidiszciplináris osztályon észlelt n-MRB Pseudomonas, illetve a sebészeti ITO MRB Acinetobactere (kiterjedten rezisztens formája). Nem bizonyult szokatlan jelenségnek az sem, hogy mindkét osztályon a pneumonia bizonyult az elsődleges, ITO-n szerzett infekcióknak [3, 18]. Itt jegyezzük meg a vizsgálatunk azon metodikai sajátságának jelentőségét, hogy az első, ITO-n szerzett kórokozó képezte a bevonás alapját. Ennek a következményének tartjuk a húgyúti és kanülasszociált infekciók minimális reprezentáltságát.

Vizsgálatunkban egyik ITO-n sem okoztak több infekciót az MRB-k, mint az n-MRB-k, a klinikai végpontokat pedig a jelen metodikánkkal nem céloztuk. Bár általánosságban sem állapítható meg, hogy a multirezisztencia minden esetben nagyobb virulenciát hoz magával, a jelenség terjedése az ITO-kon egyre nagyobb problémát jelent intézményeinkben is és világszerte. Jelen vizsgálatunk a klinikai végpontokat nem rögzítette. Ugyan rendelkezünk néhány új, akár a komplikált infekciókat okozó, rezisztens baktériumok egy részére is hatékony antibiotikummal is, mint például a ceftolozan [19], de nincs okunk feltételezni, hogy rövid időn belül az eszköztárunk jelentős bővülése lenne várható. A multire- zisztens törzsek terjedésének kedvező feltételek azonosítása így alapvető lenne. Saját vizsgálatunk olyan potenciális rizikófaktorok szerepét kívánta vizsgálni, amelyek szerepe a nosocomialis infekciók szempontjából általánosságban valószínúsíthető, illetve ezeken belül a mindennapos ellátás szempontjai alapján is reálisan figyelembe vehetők. Bár okunk volt számos társbetegség, az állapotsúlyosság, illetve az ITO-s kezelés, a lélegeztetés, megelőző (esetlegesen elhúzódó) antibiotikum-terápia hosszának hatását feltételeznünk az MRB-rizikó fokozásában $[20,21]$, ez csak kevés esetben volt igazolható.

Az általunk kiemelt néhány társbetegség szerepét az egész vizsgált intenzív beteganyagon értékelve megállapítottuk, hogy a dohányzás olyan igazolt rizikófaktora a multirezisztens baktériumoknak, amely a COPD fennállásától független. Ezen megfigyelés elsősorban a multidiszciplináris ITO-ról érkezett adatokból következik. Mint VAP-rizikófaktor, talán nem szorulna külön kommentárra, a kritikus betegellátásban tapasztalatunk szerint mégis sokszor felületesen dokumentált, a fokozott MRB-kockázat újabb érv lehet az érintett betegek azonosítása mellett. A malignus betegségek esetében a nem multirezisztens kórokozók voltak gyakoribbak. Több társbetegség szerepét azonban nem sikerült igazolnunk.

Nem sikerült az ellátással, illetve az egyes terápiák idejétől függő szignifikáns összefüggést sem igazolnunk. Mind az ITO-n töltött idő, mind pedig a lélegeztetés vagy az antibiotikum-terápia megelőző időtartama olyan tényezőnek bizonyult, amely egyik ITO-n sem fokozta érdemben az MRB-k rizikóját. Nem találtuk meghatározónak a stresszulcus-profilaxis módját sem.

Ezen utóbbi jelenségek, véleményünk szerint, nem feltétlenül mondanak ellent korábbi ismereteinknek. Egy P. aeruginosa-fertőzéseket vizsgáló közlemény a diabetes mellitust, illetve magát az intenzíves felvételt azonosította a multirezisztens törzsek rizikófaktoraként [21]. Egy már speciálisan intenzív populációt és a mi vizsgálatunkhoz hasonlóan az MRB-ket egységes csoportként vizsgáló tanulmány a megelőző fél éven belüli hospitalizációt, az ellátás (ITO, illetve küldő osztály) során alkalmazott fluorokinolon-, carbapenem-, aminoglikozidhasználatot, illetve az AIDS fennállását találta rizikófaktornak, a diabetest például már nem [20]. Az egyes vizsgálatok között, a módszerbeli különbségeken túl, a legjelentősebb különbségek az adott osztályok jellemzőiben és a vizsgálat alatti saját flórájában lehet. (A másodikként idézett vizsgálatban például a leggyakoribb patogén az MRSA volt.)

Saját vizsgálatunk eredményei alapján úgy gondoljuk, hogy az időtől függő rizikófaktorok igazolhatósága vagy annak hiánya erősen függhet a multirezisztens törzsek részarányától. „Kiegyensúlyozott” arányú, de jellemző kórházi törzsekből álló saját flóra esetén az ITO-n töltött, illetve lélegeztetve töltött napok számával elsősorban talán az adott osztály flórájának kolonizáló, majd fertőző hatása érkezik el, nem pedig egyértelműen a multirezisztens törzsek többségbe kerülése. Mindazon- 
által ez a hatás a két részt vevő osztály között is különbözôen alakult, a sebészeti ITO-n négy-öt, a multidiszciplináris ITO-n hét nap lélegeztetés után találkoztunk a jellemző patogénekkel. Ezek az időtartamok a jellemzően időtől függő ITO-s rizikófaktorok számára valójában rövidek. A miénkhez hasonló metodikával, de már valamennyi ITO-n szerzett kolonizáció és infekció felmérése a jövőben valószínúsíthetően közelebb vihetne ezen rizikófaktorok pontosabb jellemzéséhez. Az eredményeink által leírt helyzet azonban sajnálatosan tudatosítja bennünk, ma nagy az esélye hazánkban, hogy a felvételt rövid időn belül követôen $M R B-t$ akvirálnak az intenzív betegek, ehhez nincs szükség elhúzódó kezelésre.

Vizsgálatunk korlátjának tekinthető, hogy a multirezisztens kórokozók egységes csoportnak tekintése valójában mesterséges, nem mikrobiológiai csoportosítás. Alacsonyabb esetszámunk, véleményünk szerint, nem tett volna lehetővé alcsoport-analízist sem a baktériumok részletesebb csoportosítására, sem az egyes antibiotikumok okozta szelekciós hatás vizsgálatára.

Eredményeink alapján saját gyakorlatunkban a szigorúbb infekciókontroll, a mindenkor jellemző patogéngyakoriság rendszeres értékelése alapvető. Minden intenzív osztály számára javasolható a saját flóra rendszeres felmérése. Munkatársaink a szakdolgozói oktatás pozitív hatását igazolták; a pozicionálás, kézhigiéné, protokollarizált légúti leszívások, illetve a betegek szájhigiénéjének kontrollja a ventilátorasszociált pneumonia prevalenciáját közel felére csökkentette (21,5/1000 lélegeztetett napról 12,0-re). Ugyanezen vizsgálat azonban a jellemző kórokozói spektrumban már nem talált jelentős változást [22].

Saját adatainkra támaszkodva javasolható a lélegeztetés első hetének végén, az akár egyéb klinikai októl függetlenül is, surveillance-minták vétele. A pozitív mikrobiológiai minta azonban a klinikai képpel együttesen, kritikusan értékelendő, mivel önmagában antibiotikum adására ösztönöz. A rendelkezésre álló adatok alapján az így azonosított betegek esetleges elkülönítését javasoljuk, a tünetmentes kolonizációk antibiotikus kezelése mellett nincs egyértelmû bizonyíték.

Dohányzó betegeink kifejezetten gyakori MRB-infekciói felhívják a figyelmet a betegcsoport esendőségére, fokozott infektológiai követésük szükségességére, akár az empirikus antibiotikum-választás eltérő stratégiájának szükségességére is.

Anyagi támogatás: A közlemény megírása, illetve a kapcsolódó kutatómunka anyagi támogatásban nem részesült.

Szerzői munkamegosztás: Sz. M.: A vizsgálat megtervezése, az adatgyưjités egy része, statisztikai értékelés, a kézirat megszövegezése. K. N.: Adatgyüjtés a vizsgálat I. Sebészeti Klinikán zajló részéhez. D. K., G. J.: A kézirat szövegezésében, véleményezésében nyújtott iránymuta- tó segítség. G. J.: Az Aneszteziológiai és Intenzív Terápiás Klinikán gyưjtött adatok feldolgozásának engedélyezése. A cikk végleges változatát valamennyi szerző elolvasta és jóváhagyta.

Érdekeltségek: A szerzőknek nincsenek érdekeltségeik.

\section{Köszönetnyilvánítás}

A szerzők köszönetet mondanak a Semmelweis Egyetem Kórházhigiénés Osztályának a mikrobiológiai adatok rendszeres, összesített rendelkezésre bocsátásáért. A levelező szerző itt fejezi ki köszönetét Prof. Dr. Csomós Ákosnak és Dr. Iványi Zsoltnak a vizsgálat tervezéséhez nyújtott kezdeti tanácsaiért.

\section{Irodalom}

[1] Vincent JL, Rello J, Marshall J, et al. International study of the prevalence and outcomes of infection in intensive care units. JAMA 2009; 302: 2323-2329.

[2] De Backer D, Biston P, Devriendt J, et al. Comparison of dopamine and norepinephrine in the treatment of shock. N Engl J Med. 2010; 362: 779-789.

[3] Tabah A, Koulenti D, Laupland K, et al. Characteristics and determinants of outcome of hospital-acquired bloodstream infections in intensive care units: the EUROBACT International Cohort Study. Intensive Care Med. 2012; 38: 1930-1945.

[4] Hanberger H, Arman D, Gill H, et al. Surveillance of microbial resistance in European Intensive Care Units: a first report from the Care-ICU programme for improved infection control. Intensive Care Med. 2009; 35: 91-100.

[5] Lambert ML, Suetens C, Savey A, et al. Clinical outcomes of health-care-associated infections and antimicrobial resistance in patients admitted to European intensive-care units: a cohort study. Lancet Infect Dis. 2011; 11: 30-38.

[6] Magiorakos AP, Srinivasan A, Carey RB, et al. Multidrug-resistant, extensively drug-resistant and pandrug-resistant bacteria: an international expert proposal for interim standard definitions for acquired resistance. Clin Microbiol Infect. 2012; 18: 268-281.

[7] van Duijn PJ, Dautzenberg MJ, Oostdijk EA. Recent trends in antibiotic resistance in European ICUs. Curr Opin Crit Care 2011; 17: 658-665.

[8] Szabó M, Bozó A, Soós S, et al. Outbreak of vancomycin-resistant enterococci in a surgical intensive care unit. [Vancomycinrezisztens Enterococcusok megjelenése sebészeti intenzív osztályon.] Orv Hetil. 2015; 156: 779-784. [Hungarian]

[9] NBS Annual reports. National Center for Epidemiology: Results of antibiotics resistance obtained from microbiologic surveillance in Hungary. [Nemzeti Bakteriológiai Surveillance Adatfeldolgozó Csoport. A magyarországi mikrobiológiai surveillance antibiotikum rezisztencia eredményei.] Országos Epidemiológiai Központ, Budapest, 2013. [Hungarian]

[10] Zilberberg MD, Shorr AF, Micek ST, et al. Multi-drug resistance, inappropriate initial antibiotic therapy and mortality in Gram-negative severe sepsis and septic shock: a retrospective cohort study. Crit Care 2014; 18: 596.

[11] Micek ST, Wunderink RG, Kollef MH, et al. An international multicenter retrospective study of Pseudomonas aeruginosa nosocomial pneumonia: impact of multidrug resistance. Crit Care 2015; 19: 219 .

[12] Lorente C, del Castillo Y, Rello J. Prevention of infection in the intensive care unit: current advances and opportunities for the future. Curr Opin Crit Care 2002; 8: 461-464.

[13] European Committee on Antimicrobial Susceptibility Testing. Rationale for the clinical breakpoints. 2015. http://www.eucast. org 
[14] European Surveillance of Healthcare-Associated Infections in In tensive Care Units. HAIICU Protocol v1.01 STANDARD and LIGHT. ECDC, 2010.

[15] Le Gall JR, Lemeshow S, Saulnier F. A new Simplified Acute Physiology Score (SAPS II) based on a European/North American multicenter study. JAMA 1993; 270: 2957-2963.

[16] Vincent JL, Moreno R, Takala J, et al. The SOFA (Sepsis-related Organ Failure Assessment) score to describe organ dysfunction/ failure. On behalf of the Working Group on Sepsis-Related Problems of the European Society of Intensive Care Medicine. Intensive Care Med. 1996; 22: 707-710.

[17] Mehta AJ. Alcoholism and critical illness: A review. World J Crit Care Med. 2016; 5: 27-35.

[18] Vincent JL, Rello J, Marshall J, et al. International study of the prevalence and outcomes of infection in intensive care units. JAMA 2009; 302: 2323-2329.

[19] Goodlet KJ, Nicolau DP, Nailor MD. Ceftolozane/tazobactam and ceftazidime/avibactam for the treatment of complicated intra-abdominal infections. Ther Clin Risk Manag. 2016; 12 : $1811-1826$
[20] Da Silva Winter J, Dos Santos RP, de Azambuja AZ, et al. Microbiologic isolates and risk factors associated with antimicrobial resistance in patients admitted to the intensive care unit in a tertiary care hospital. Am J Infect Control 2013; 41: 846-848.

[21] Fernández-Barat L, Ferrer M, De Rosa F, et al. Intensive care unit-acquired pneumonia due to Psendomonas aeruginosa with and without multidrug resistance. J Infect. 2017; 74: 142-152.

[22] Mogyoródi B, Dunai E, Gál J, et al. Ventilator-associated pneumonia and the importance of education of ICU nurses on prevention - Preliminary results. Interv Med Appl Sci. 2016; 8: 147-151.

(Szabó Marcell dr., Budakeszi, Pátyi út 51/D, 2092 e-mail: szabo.marcell@med.semmelweis-univ.hu)

\section{NOTA \\ Új fejlesztés az egészségügyben dolgozók, tanulók részére!}

A magyar nyelvứ szakirodalmi keresőszolgáltatás

\section{MI a NOTA? \\ Napivizit Orvosi Tudástár Alkalmazás}

Mit tud a NOTA portál?

Megkönnyíti a magyar nyelvü szakirodalmi források keresését.

Eszköztől függetlenül, akár okostelefonról, a betegágy mellett állva is használható.

\section{Miben kereshet a NOTA-val?}

Az Akadémiai Kiadó folyóirataiban: Orvosi Hetilap, Magyar Sebészet, Mentálhigiéné és Pszichoszomatika.

Más kiadók magyar nyelvü

szakfolyóirataiban: pl. Lege Artis Medicinae, Hypertonia és Nephrologia, Ideggyógyászati Szemle.

A hatályos szakmai irányelvekben.

Magyar nyelvủ kérdésekre adott angol nyelvű találatokban, a PubMeden.

\section{nota.hu}

Amennyiben további információra lenne szüksége, keressen minket elérhetöségeinken: journals@akademiai.hu/hirdetes@akademiai.hu

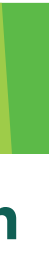
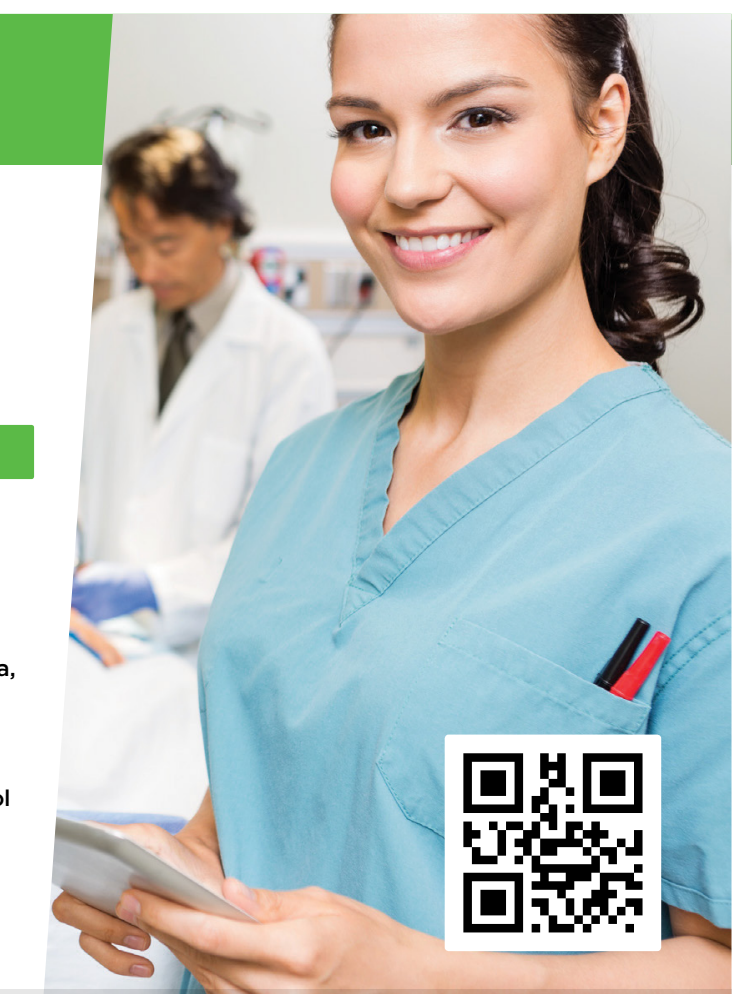

\section{Akadémiai Kiadó}

A Wolters Kluwer Csoport tagja

1117 Budapest, Prielle Kornélia u. 21-35. / Telefon: (1) 464-8246

www.akademiai.hu / www.akademiai.com
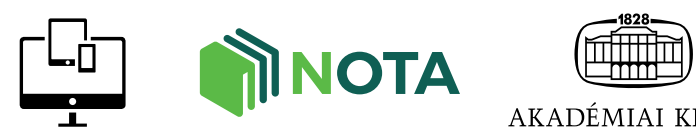

AKADÉMIAI KIADÓ 